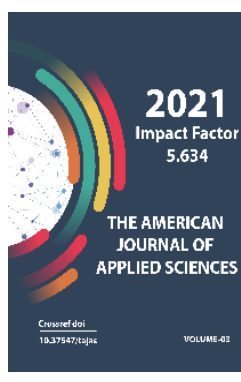

Journal Website: http://usajournalshub.c om/index,php/tajas

Copyright: Original content from this work may be used under the terms of the creative commons attributes 4.0 licence.

\section{Affect Of External Factors And Non-Native Community In Children's Personality And Its Impact In Second Language Acquisition}

Feruza Tulibayevna Jumaniyozova

The EFL/ESL Teacher Of The Uzbekistan State World Languages University, Tashkent, Uzbekistan

\title{
ABSTRACT
}

The research presented in this article is about the challenges young learners may face when they are exposed to non-native communities, and introversion which stems from these kinds of situations. This paper focuses on three different problems: (1) the effect of external factors and non-native community in a child's personality: (2) the impact of changing schools with different medium instructions frequently (3) the effect of introversion on the children's Second Language Acquisition. This case study is based on three research tools, such as an interview, lesson observation, personality test to affirm the feeling the subject underwent because of the mobile lifestyle of his parents.

\section{KEYWORDS}

Culture, mobile child, residential mobility, personality, introversion, extroversion, L2, language acquisition.

\section{INTRODUCTION}

Families change their residence for several reasons, such as job responsibility, preferring an alternative lifestyle, unsatisfactory living conditions, and adult relationships. Not only do people have to change their residence but also their languages if they move to a country 
where their native language is not an official language. Frequent exposure to various cultures and languages affects children's personality, as well as their language acquisition. Changing schools with different medium instructions may demotivate and discourage a child, leading to a lack of confidence in the child.

\section{LITERATURE REVIEW}

Leading a mobile lifestyle has several drawbacks, as well as benefits. Adults can adapt to different situations quickly; however, children are not as versatile as adults, and they may encounter many hindrances. Parents hope that moving to a foreign country may be useful for their children to be multilingual and multicultural. However, residential mobility has more negative sides rather than positive. First, because of moving to a foreign country, a child loses ties with relatives, friends, and close adults. Social Capital theory (Coleman,1988) argues that this relationship is crucial in the child's development, cognitive capacity, and social functioning. Because of the feeling of loss, a child may encounter psychological distress following the atmosphere of alienation. In adjusting to an unfamiliar environment, a child suffers from homesickness, loneliness, and anxiety, and it can bring to lower mental prosperity in the long term (Oishi and Talhelm, 2012). In every culture, there are their own rules and norms, and a newcomer has to cope with the demands of the situation. Besides, it is more challenging when a child has to change schools with different medium instructions each time. Changing schools may bring about reduced educational accomplishment (Boon, 2011). In most cases, residential mobility and exposure to new languages may activate introversion in a child's personality and affect his/her second language acquisition. Human personality has been the principal subject for researches, and I have conducted substantial studies on this theme so far. Scholars like Krashen (1985), Skehan (1989), Gass and Selinker (1994), have worked on the effect of personality in SLA. Many personality characteristics can either help or influence negatively on the learning process. The consequence of introversion and extroversion was first studied by Eysenck. He argued introverts were better learners than extroverts. However, many SLA researchers believe extroverts can gain language properly since they prefer the communicative approach (Cook, 2001), which is the principal means of language learning. Extroverts are sociable, talkative, energetic, and actively take part in classroom activities. They are thought to be successful in L2 Communication and interaction help students to receive a language thoroughly and increase the students' output in L2 (Swain, 1985). Introverts are defined as being reserved, shy, thoughtful and show a passive engagement in the classroom projects. Introversion does not always lead to language deficiency, since an introverted student can be a quiet observant learner and achieve brilliant success in language learning (Lily WongFillmore, 1979).

\section{MATERIAL AND METHODS}

Living and studying in diverse, multicultural, non-native communities, the subject confronted various problems such as adapting new culture and environment, learning to study in different schools with Russian medium instruction and English medium instruction, and finding new friends each time when they moved to a new foreign country. His reoccurred exposures to several languages and cultures has changed his personality from extrovert to introvert and made him an 
introverted-extrovert person. His multilingual learning experience has helped him to be multilingual and flexible in any learning environment. It is visible from the fact that he knows several languages, including English, Russian, Spanish, and Uzbek.

The student I worked with is a freshman student at the academic lyceum under the Uzbekistan State World Languages University (UzSWLU). B (the name is changed) is a 16year-old boy who has been living for approximately four years in Uzbekistan. Other times, he had to lead a mobile lifestyle in different countries like Malaysia and the USA because of his parents' job. For the first time, he moved to New-York, one state of America. It was a hard period for him as he did not know the English language at all. His parents gave him to a kindergarten so that he could learn English better. Because of the unfamiliar environment and non-native community, B felt anxious, lonely, and unsafe. Not knowing any word in that language, he had to go to extra two-hour tutorial courses after studying in the kindergarten for six hours in the mornings. It was hard for him to find new friends in a foreign city, as he could not interact with local children in their language. After six months of attendance at kindergarten, he was at the age of studying at school. He could not join school because he was still not ready for starting the study. Therefore, his parents decided to postpone the commencement of the school by prolonging the kindergarten duration. Next year, he eventually began studying at a local American school with English Medium Instruction (EMI). B attended American school until 3 rd grade and then, he again faced a new difficulty since his parents had to return to Uzbekistan. Coming to the native country, B had to continue studying in a local school with
Russian Medium Instruction since his parents could not afford the international school. Now, it was a real challenge for $B$ as he was used to the American environment and its language. Even though $B$ had attended this school for a year, he could not get accustomed to a new atmosphere. The first week at school was so stressful that he even refused to go to a new school; however, he had no option but attending. After one-year of attendance, $B$ had to move to Malaysia with his family. In Malaysia, his parents attempted to give him to the local school with English Medium Instruction. Thus, he continued studying in English school again and stayed in Malaysia for almost two years. After all, B returned Uzbekistan with his mother and went on attending to his former school in the previous local Uzbek school. From 7th grade till 9th grade, he studied in that school with Russian Medium Instruction. In August 2019, B entered the academic lyceum under UzSWLU and now, he is one of my diligent students. Having been teaching $\mathrm{B}$ for two months, I observed and evaluated his attendance and performance during the lesson. At first, based on his averse behavior in class, I thought that he did not know English adequately. Knowing more about his past, I realized that many external factors from his childhood background precluded him from being a sociable and active student. Even though he is reserved and introverted in personality, I would describe him as a talented, deep-observant, and intelligent student.

From the beginning of the semester, B's sitting at the back without talking to anyone drew my attention as a teacher. Even though his English was quite well, he did not want to join activities. The reason why I was surprised at his behavior is that he was the only student I have ever seen, who avoided showing off his 
language abilities even though his English was quite well. He would not make effort to take higher grades and answer the questions during the English classes. However, from time to time, he performed his willingness to be close to his group-mates. Therefore, this study triggered curiosity in me and started to scrutinize B's personality. Three-step research has been planned: an oral interview, Eysenck's Personality Inventory test, and a two-week observation of the student at English lessons.

\section{STAGE 1.}

The interview was conducted to collect data about the subject's background, English level, the reason for his introversion. The interview consisted of 20 main questions: 6 questions about his background, family, and personality; 4 questions about his English learning experiences; and 11 questions about his residential mobility. The interview was conducted one-by-one in a classroom of the lyceum that I work.

\section{STAGE 2}

To define the subject's personality, I used two types of personality tests. First, I applied a simple quiet quiz, and it consisted of 20 questions. The questions were formed do determine the level of introversion and extroversion. The subject should have to answer by choosing true or false. The second personality chosen was 'Eysenck's Personality Inventory' test, which was invented in 1964 by Eysenck.

\section{STAGE 3}

In order to identify my learner's level and his performance during the lesson, I conducted a two-week lesson and observed my student. The course-book used for the 1st-semester course is the B2-level of Complete IELTS published by Cambridge University Press. However, his level is higher than B1. Therefore, I decided to give him extra materials for homework. During the lessons, I used activities that require individual work, pair work, and group work to identify his reaction in different approaches. It was intensive two-observation and totaled to six lessons.

1-lesson: interactive game "Like Dislike and Neutral" was implemented to create an active friendly environment. The aim of the game was to promote students speaking and critical thinking skills.

2-lesson: "debate" lesson. The topics were distributed to students to let them choose one interesting topic and students worked in groups.

3-lesson: online game "Quizlet" used to revise the previous lessons vocabulary and grammatical rules. Students worked in groups.

4-lesson: students presented "the project works" they prepared. The free topic presentation was given to the students in the previous lesson as homework.

\section{RESULTS}

Based on the collected data as an interview form, it became clear that the subject had experienced difficult times before starting to study at the lyceum. Living and studying in different cultural situations affected his personality. He acknowledged several times how difficult it was for him to change places and schools. This is the part of the interviewFeruza Jumaniyozova (FJ) is an interviewer and the student is BR:

FJ: So, where do you study? And what do you study? 
BR: I study in a lyceum under UzSWLU. I study in a exact science class. So Physics, Mathematical science, and Geometry. I am a freshman. I got accepted in the beginning of this year.

\section{FJ: How do you feel know?}

BR: I feel motivated and energetic. In the past, studying in different countries and in different schools, I was lost and confused. However, now I realized I also can be a leader and important person.

Because of his parents' job, $B$ had to change his home and friends several times and adapt to a new environment each time. As Lenneberg (1967) claimed, if a child is not exposed to a language in a critical period, he/she can not learn his/her native language fluently. However, from my student's experience, it can be seen that the child's exposure to different languages, also affects his personality. This is the part of the interview:

FJ: So, how did it happen?

BR: When I was 5, we moved to America because of my father's job.

FJ: Did you know English when you went there?

B: Not at all. I did not know even a word.

FJ: can you tell me more about it?

BR: Sure... Well, as I said, when I moved to America I did not know any word in English. My parents gave me to the local kindergarten and I started learning English in this way. For the beginning, it was really difficult for me to adapt to a new environment. I could not make friends with local children since I did not know their language. I used to cry every day asking my parents to return our home. In the mornings, I used to go to the kindergarten for 5 years and in the afternoons to the English tutorial courses for two hours. After six months, it was time for me to go to school, but I did not go to school. Instead I left at the kindergarten one more year to learn English better. Next year I went to school and studied there for three years. Then, we came back to Uzbekistan.

FJ: Did you study in English school here, too?

BR: No, unfortunately... (smiles). I studied here in Russian school. Because international school costs a lot, and my parents could not afford it. So I had to study in Russian school and learned Russian language too. It was really confusing, and I did not know whether I should learn Russian or my school subjects. I studied in that school for a year and left for Malaysia with my family. My parents saw how difficult it was for me to study in Russian after studying in English for three years and gave me to an international school in Malaysia. I studied in an English school for three months and it was difficult for my parents to afford it, so they had to give me to a Russian school again. I studied in a Russian school for two years in Malaysia. After miserable two years in Malaysia, I returned to Uzbekistan with my mom and continued my study in my previous Russian school. The hardest part of everything that I have done was not learning new languages, it was adapting to new environments and always leaving soon.

According to Social Capital Theory developed by Coleman (1988), children have to lose their relationship with their friends and close people when they move abroad, and it affects their personality, hindering their social functioning, cognitive capacity, and development as a child.

Even though the subject started learning English when he was 5, and studied in the EMI school, he was not confident to show his 
language ability. During the lessons, he sat at the back, being reluctant to join classes and his group-mates. The reason why he did not follow the class was he considered this lyceum was also one of the transient situations. As a result of the movable lifestyle, he de-motivated to perform his leadership abilities in classes. This is the part what he said about friendship:

FJ: Bobur, you have lived in different countries and been different situations. What do you think you learned from these all?

BR: Living abroad or in Uzbekistan, I have learned that having friends is important but being a good friend is even more important than that. And to be a good friend I have to be dependable. I have to be someone who will try their best to do as my friends asked me to. Being a good friend does not mean being dependable, it also means being honest to the point of being veracious.

According to many linguists, extroversion is helpful in language learning, and extrovert learners can learn more during the lessons. Extrovert learners can demonstrate themselves in the activities that require communicative skills, however, this study shows that introvert students can be also successful in language learning since they are more observant and can learn a language deeply. This interview with $B$ gave thoughtprovoking information.

To check my hypothesis on whether the subject's introversion is intrinsic or extrinsic, I decided to investigate his introversion and extroversion level as the second stage of my research. The first personality test was named "Quiet Quiz", and his answers to 14 from 20 questions showed that he is introvert. The second personality test was called "Eysenck's Personality Inventory", and in this test, B's answers performed that he is choleric, which is the division of extroversion. We also used many online personality checkers, and in many of them, he was extrovert. From this information, I can conclude that B is introverted-extrovert, which means he is extrovert inside.

The third step was lesson observation and in the lessons, to check the reaction of the subject to different activities: I used individual work, pair work, and group work activities. In the first lesson, after teaching the grammar topic "present perfect tense" and the 3 rd unit from the book "Complete IELTS", I used the group activity to enhance students' speaking ability. The students' job was to choose a topic and justify that it is a spectacular place to go and convince others to join them. However, I saw a lack of interest in B and he rarely spoke even though his English was better than others.

In the second lesson, explaining the main theme, I drew students' attention to the online "Quizlet" game. This game was based on the vocabulary and grammar rules which the students learned during the previous lessons. The students were remarkably inspired to finish this game first and B was also highly enthusiastic to complete it before others. Then, I realized that $\mathrm{B}$ was good at solitary work. To solidify my hypothesis, I told all the students to prepare a presentation for the next lesson individually.

In the third lesson, B prepared a presentation about New-York. He explained everything thoroughly with enthusiasm. in order to motivate him, I praised him among the students, telling others that he had perfect English. 
In the last lesson, I organized a debate on the theme "Benefits and drawbacks of studying abroad" and this time B also participated in the discussion with interest.

\section{CONCLUSION}

Concluding, great attention is important in children's development and Second Language Acquisition. As the importance of speaking and interacting with children in the Critical Hypothesis Period, caring for children's psychology and their cognitive development is also an indispensable factor. Before moving to other countries, first of all, parents should think carefully about their children's future and their adaptation to a new environment. Each child has different psychology and character, and their adaptation to a new culture may affect them seriously. Dealing with introverted or ambivert students is not the only responsibility of parents but also teachers' duty.

As Coleman (1988) proved the relationship with relatives and close people is vital in children's being well-nurtured, psychologically healthy individuals in the future.

One more important factor that should be mentioned here is the motivation which a child can take not only from teachers but also from their parents. It is an indispensable part of their life and with the motivation, they can achieve success in learning languages and gain their goals in life.

\section{REFERENCES}

1. Boon, H. (2011) School moves, coping, and achievement: models of possible interactions. J Educ. Res. 104. 54-70.

2. Cook, V. (2001). Second Language Learning and Language Teaching (3rd ed.) London: Arnold.

3. Coleman, J. C (1988). Social Capital in the Creation of Human Capital. The American Journal of Sociology, Vol. 94, Supplement: Organizations and Institutions: Sociological and Economic Approaches to the Analysis of Social Structure (1988), pp. S95-S120. The University of Chicago Press

4. Eysenck, H. J., \& Eysenck, S. B. G. (1993). Eysenck Personality Questionnaire-Revised (EPQ-R) [Database record]. APA PsycTests. https://doi.org/10.1037/t05461-000

5. Eric H. Lenneberg (1967) Biological foundations of language. New York: John Wiley and Sons

6. Hess, N. (2005). Cambridge handbooks for Language Teachers: Teaching Large Multilevel Classes. Cambridge University Press.

7. Lighbown, P.M. \& Spada, N. (2013). Individual Differences in Second Language Learning. How Languages are learned(4th Ed., PP. 75-100). Oxford, UK: Oxford University Press.

8. Oishi, S., \& Talhelm, T. (2012). Residential mobility: What psychological research reveals. Current Directions in Psychological Science, 21960, 425-430. http://dx.doi.org/10.1177/096372141246 0675 
The American Journal of Applied sciences (ISSN - 2689-0992)

Published: April 30, 2021 | Pages: 233-240

Doi: https://doi.org/10.37547/tajas/Volume03lssue04-33

9. Swain, M. (1985). The output

Hypothesis: Some roles of

comprehensible input and

comprehensible output in its

development. In S. M. Gass, \& C. G.

Madden (eds.), Input in second

language acquisition. Rowley, MA:

Newbury House, 235-252. 